\title{
УЛАЗАК КОРОНЕ У СРПСКИ ЈЕЗИЧКИ СИСТЕМ
}

\begin{abstract}
Невоља која је снашла читав свет од краја 2019. године у виду појаве и агресивног ширења новог, дотле непознатог вируса корона своје место морала је наћи и у језичким системима. У овоме раду је на основу грађе из српског језика показано у којој мери је увећана породица речи у вези са тим вирусом и болешћу коју он изазива, као и начин на који се те лексеме обликују, пишу и уклапају у српски језички систем, али и путеви којима ће се проширење даље одвијати.
\end{abstract}

Кључне речи: корона, ковид, лексема, синтагма, језички систем.

\section{1. Увод}

Почетком 2020. године разједињени свет ујединила је заједничка невоља у виду појаве новог и дотле у тој форми непознатог вируса названог корона. Назив је настао на основу изгледа (личи на круну). Термин ковид представља скраћеницу од лексеме вирус и назива, тј. имена овог вируса $\kappa_{\text {корона }}^{2}$ и он је скован као назив за болест коју овај вирус изазива ${ }^{3}$, мада се према употреби у свакодневној комуникацији (и у медијима) такав закључак не би могао извести - и један и други термин користе се и као назив вируса и као термин за болест изазвану тим вирусом ${ }^{4}$.

Вирус је агресивно освојио свет, а на исти начин и назив овог вируса, ове болести и свега што је у вези с тим ушло је у језички систем сваког појединачног језика и води борбу да се у тај систем уклопи и у њему устали. Ако се има у виду чињеница да је језик архива свега што је у људској историји било, очекивано је и логично да и све што је у вези са овом најновијом појавом нађе своје место у језичком систему. За ову прилику начињено је истраживање у којој мери, у ком облику и на који начин су термини у вези са овим успели да се „уселе” у српски језички систем, мада би заправо адек-

\footnotetext{
${ }^{1}$ jordana.markovic@filfak.ni.ac.rs

2 Овај назив (ковид) заправо буквално значи 'крунски вирус'.

${ }^{3}$ Ваља имати у виду да овај назив има три (са бројем 19 заправо четири) дела и да је завршни део (д) скраћеница од енглеске речи болест (disease).

${ }^{4}$ Према ономе што стоји на сајту Министарства РС („Ради се о новом соју коронавируса који пре није био откривен код људи. Болест узрокована тим вирусом назива се COVID-19” http:// covid19.rs), требало би да је јасно шта представља назив вируса, а шта назив болести.
} 
ватнији термин био да се „усељавају”, будући да процес тек добија замах. У ту сврху коришћена је грађа са телевизије, из средстава дневне штампе и са интернета.

Овом темом у српском језику бавиле су се Светлана Слијепчевић Бјеливук и Марина Николић са Института за српски језик, па се на сајту овог института може наћи њихов Речник појмова из периода епидемије ковид (www.isj.sanu.ac.rs).

\section{2. Лексема корона пре вируса корона}

Језик као систем знакова кроз историју се стално богатио под утицајем промена изазваних нејезичким факторима и те промене су најчешће на лексичком плану - јављају се нове речи (и спојеви речи) и постају јако фреквентне тако да прелазе у свакодневну општу употребу, што значи да се њима служи већина говорника датог језика.

Лексема корона није нова, али у свакодневни говор она сада улази у новом контексту, тј. са новим значењем. У српском језику ова лексема постоји као одредница у стандардним речницима. Тако је у Речнику српскохрватског књижевног језика забележено пет значења $\mathrm{a}^{5}$, а слично је и у Речнику српског језика 6 .

\section{3. Преглед грађе}

3.1. Грађа на основу које ће бити сачињена анализа сакупљана је из средстава јавног информисања - писаних и усмених. Велики део потиче из дневног листа Новости, понешто из дневних листова Политика, Данас и Курир, један део је забележен из различитих ТВ емисија, а доста је прикупљено и интернет претрагом.

3.2. Реч корона, како показује грађа, не само што је успела да се удоми у српски језички систем са новим значењем већ је на различите начине знатно увећала своју нову породицу. Уз једну заједничку, светску невољу која нас је задесила, јавила су се два основна лика-корона и ковид. Овај други

5 Тамо налазимо: 1. а. круна, венац. б. фиг. главна маса запаљене материје. 2. последњи овој, омотач који се за време помрачења Сунца види као венац. 3. златан сјај или круг око главе на сликама светаца, ореол, нимбус. 4. муз. знак изнад ноте који јој продужује трајање. 5. цркв. кат. Састанак свештеника једног црквеног котара.

${ }^{6}$ У овом речнику стоји: 1 . астр. Спољни слој Сунчеве атмосфере, који се види као светао венац око Сунца за време његовог помрачења. 2. светао круг око главе светаца, ореол, нимбус. 3. муз. знак у облику полукруга и тачке који се ставља изнад или испод ноте, паузе и др . и означава продужетак тона, паузе. 
лик настао је комбинацијом трију лексема: корона, вирус и болест (енглески disease). Уз облик ковид често је ишао и број 19, будући да се претпоставља да је то година његове појаве, односно његовог масовног ширења. Ови термини су у врло кратком року постали део активног вокабулара свих говорника (и вероватно готово свих језика). За њима су се убрзо јавиле и бројне изведенице, сложенице и изрази и постали део свакодневне комуникације међу људима.

3.3. К о р о н а. Термин корона (у преводу круна $)$ као назив за овај новооткривени вирус настао је на основу изгледа самог вируса. Према ономе што се у свакодневној комуникацији чује и употребљава, овај термин може се посматрати као основни назив и вируса и болести настале уласком овог вируса у организам. Такав облик, уз назив за сам вирус, ушао је у српски језички систем и као назив за стање настало као последица деловања тог вируса на људски организам. О томе сведоче сви прикупљени примери. Тако исказ „Признао да је имао корону” (Курир 29. 5. 2020) може значити да је признао да у себи има овај вирус или да се разболео под дејством овог вируса, а слично је и са примером „Уопште се није помињала корона ...” (Новости 11. 5. 2020), одакле није јасно да ли се није помињао вирус или болест и сл. Наравно, ваља имати у виду да су у питању узрочно-последични односи, те су оваква питања излишна - ако неко има вирус, готово је сигурно да има и болест без обзира на то хоће ли се она испољити у лакшем или тежем облику.

Такви су (двозначни) и сви други примери са лексемом корона:

Корона би могла тињати у Африци неколико година ТВ Нарру 10. 5. 2020; Уопште се није помињала корона Новости 11. 5. 2020; Грађани у Русији (се) сада више плаше да ће остати без посла, него што се плаше короне Новости 9. 5. 2020; До сада вакцину против короне примило више од 7.000 људи (на сајту covid 19.rs); 12. 1. 2021; Корона у Бугарској www.novosti. rs 19. 1. 2021; још 1.820 особа преминуло од короне ТВ Н1 21. 1. 2021. итд.

3.3.1. К о р о н а + в и р у с. Упркос деловању закона економичности, у језику се често уз лексему корона јавља допуна вирус, а та допуна могла се наћи у препозицији или постпозицији. Ако се нашла иза, у писању је било могуће написати две речи или једну, тј. растављено или састављено. Тешко је тврдити која је варијанта фреквентнија - то зависи и од извора који је коришћен, мада су честе напоредне употребе сва три лика. Мора се имати у виду да се о састављеном или растављеном писању може говорити једино у случају писаног језика.

\footnotetext{
${ }^{7}$ Можда посебну пажњу заслужује чињеница да се ова лексема готово не јавља у преводу тек изузетно и то вероватно у Гугловом преводу (164 корисника и 37 запослених заражено је круном у установи rs.n1 info.com 16. 5. 2020).
} 
3.3.1.1. К о р о н а в и р у с: Корона вирус букти у Латинској Америция; Руска вакцина против корона вируса; Корона вирус припада групи вируса који узрокују болест; у вези са корона вирусом у Републици Србији; негативан тест на корона вирус пре кретања на пут итд.

3.3.1.2. В и р у с к о р о н а: откао је вирус корона; Тестиран на вирус корона; За улазак довољан тест на вирус корона; Позитиван на вирус корона; Вирус корона „ушао” је; особе са инвалидитетом знају о вирусу корона; Имунолог Срђа Јанковић каже да вирус корона; мере против вируса корона остају на снази итд.

3.3.1.3. К о р о н а в и р у с. Коронавирус у бројкама; Нови случај заражавања коронавирусом; регистровано 3.505 .754 случајева коронавируса; 41 је позитиван на коронавирус; од којих је 1.646 налаза позитивно на коронавирус; у Србији је на коронавирус тестирано 2.496 .125 особа; Ради се о новом соју коронавируса који пре није био откривен код људи; још није дијагностификован нови сој коронавируса www.politika.rs 20.1.2021. ${ }^{9}$ итд.

3.3.1.4. О томе у којој форми ваља употребљавати овај лексички спој (писати и изговарати) у медијима су се оглашавали поједини лингвисти тврдећи и на сличним примерима показујући како треба. С тим у вези огласио се и Одбор за стандардизацију српског језика са тврдњом: „Најисправније је писати: вирус корона, дакле, тако што се реч вирус пише на првом месту", будући да се ради о атрибутивној конструкцији, ,а правило је да у свим таквим конструкцијама (синтагмама) шири појам долази испред ужег”. „Како је корона само тип вируса, нормално је да се по датом правилу пише вирус корона" (http://www.isj.sanu.ac.rs. од 4. фебруара 2020).

3.3.2. К о в и д. Лексема ковид ${ }^{10}$ представља кованицу насталу из споја делова речи корона, вирус и болест (енглески disease) - ко-ви- $\partial$, чему је често додата и бројка 19. Овако настала лексема требало би да послужи као термин за назив болести изазване дејством вируса корона. Међутим, будући да су се у кратком року појавиле две дотле ширем слоју непознате лексеме за једну невољу која је снашла свет, као да није било довољно времена да се разлуче ова два термина - и медији и обичан свет у свакодневном општењу почели су их користити синонимно и за болест и за узрочника те болести.

3.3.2.1. О томе да се лексема ковид употребљава синонимно са корона сведоче примери:

Ковид највише удара на срчане болеснике; Ковид су у институт ... унели; Да ће ковид највише нападати; од последица ковида преминуло 1.820

\footnotetext{
${ }^{8}$ У наставку рада биће изостављен податак о извору из којег потиче пример ради уштеде, будући да је интернет претрагом лако пронаћи извор.

${ }^{9}$ Иван Клајн, залажући се за термин вирус корона, истиче да је Политика, после оглашавања лингвиста, прихватила предложени термин, што овај пример оповргава (http://www.nin.co.rs).

${ }^{10}$ Овај лик заправо представља лексикализовану скраћеницу у српском језику.
} 
људи; масовна вакцинација против ковида званично почиње; руска вакцина против ковида итд.

Можда дилеме да је у питању болест нема у следећим примерима: План активирања капацитета за ковид; Да је неко прележао ковид итд.

3.3.2.2. К о в и д 19 (к о в и д-19) / C о v i d 19 (С o v i d-19)

Показало се да ковид 19 највише „љуби”; 22 позитивно на ковид 19; Ковид 19 однео је и трећег члана породице Ракић; вакцине против ковида 19 итд.

Победио си Covid 19? Донирај плазму;

COVID-19 различито делује на људе. (са сајта covid19.rs) итд.

3.3.2.3. О колебању у употреби сведоче примери са ,удвојеним” (или троструким) облицима:

Како да заштитиш своје ментално здравље током пандемије корона вируса (COVID-19); Ако имате питања о вирусу корона - coronavirus (COVID-19);

3.3.2.4. В и р у с к о в и д 19. Синонимну употребу, тј. несигурност у употреби новостворених термина, потврђују следећи примери у којима је очигледно да је вирус (а не болест) назван ковид, тј. ковид 19 (ковид-19), односно covid-19:

Један је од првих заражених вирусом ковид 19; Вирус ковид-19 однео 33000 живота;

Статистички подаци о вирусy covid-19 у Републици Србији.

3.3.3. Н о в о н а с т а л и с п о ј е в и (са корона или ковид). О језичкој агресивности ових лексема сведоче бројни новонастали облици - изведенице, сложенице, полусложенице или синтагматски спојеви. Истина, из усменог говора се не може увек знати када је у питању синтагма, а када полусложеница или композит - то је видљиво у писаном језику, под условом да је „писац” имао добар осећај за те нијансе, што није увек било могуће, о чему често сведоче две варијанте у истом тексту.

3.3.3.1. И з в е д е н и ц е. У Речнику појмова из периода епидемије ковида јављају се релативно бројне изведенице: ковидаш, коронарац, коронаи, коронашица, ковидащчја, коронација, коронача и коронизащчја ${ }^{11}$. У мојој грађи није било речи насталих деривацијом. ${ }^{12}$

3.3..3.2. С л о ж е н и ц е. Систем се проширио стварањем сложеница. Оне су настале спајањем лексеме корона или дела лексеме ковид (ков) и неке друге речи или дела друге речи.

\footnotetext{
11 Значење ових и других надаље коришћених речи из овог речника може се наћи на сајту Института за српски језик САНУ.

12 Заправо, јавио се облик са префиксоидом у саставу једног синтагматског модела (посткорона синдром).
} 
У Речнику појмова из периода епидемије ковида налазе се: коронафобија, корономанија, коронтин и ковидиот ${ }^{13}$. У мојој грађи су се нашла само три композита (ковидиот, Ђоковид и коваксин):

Какав ковидиот: ушао у продавницу без маске, Како препознати „ковидиота”? на светској ранг листи Ковидиота; награду за „Ковидиота” године; прогласио је најбољег тенисера света Новака Ђоковића за "ковидиота" године; прогласио је Нејмара за ковидиота ${ }^{14}$ дана итд.

Новак је Боковид- 19 .

Појава лексеме ковидиот сматра се резултатом глобализације.

3.3.3.3. П о л у с л о ж е н и ц е: Овај творбени модел обавезно припада писаном језику, будући да је изговор ове речи са цртицом немогуће разлучити од изговора двеју речи.

3.3.3.3.1. Проглашавајући Црну Гору за корона-фpи; Црна Гора себе проглашава корона-фри државом; Имамо најбољу „корона-кореографију”; Реакције других земаља на пандемију назвао је „корона-психозом” итд.

3.3.3.3.2. Бројније су полусложенице са лексемом ковид, чему доприноси фреквентност употребе таквих модела:

Да не би ушли у ковид-амбуланте и били у контакту; Динамика затварања ковид-болница; Кроз нашу ковид-болнииу прошло је око 90; У КОВИД-болници у Лесковцу; Са симптомима ковид-инфекције; На пијацама у Италији уведено ново занимање - ковид-менацер; Могућност увођења ковид-nасоша; Ковид-пасоши улазе на мала врата; Отпустити све ковид-nацүијенте; Ковид-пацијенти на одељењу; Из ковид-система излази и Општа болница; изласка из ковид-система итд.

Очигледно је да овакав творбени модел наилази на погодно тле и да hе се јавити велики број оваквих комбинација, мада у Речнику појмова из периода епидемије ковида таквих творбених модела нема.

\footnotetext{
${ }^{13}$ у Речнику појмова из периода епидемије ковида стоји да је ова лексема у синонимији са корона идиот, а У Политици се јавља синонимна форма вирус корона-идиоти којом се објашњава ужи појам „ковидиоти”.

${ }^{14} \mathrm{У}$ вези са овом кованицом јавила су се и бројна тумачења (Спутник Србија, дневни лист Политика). Нешто шире тумачење стоји на сајту jezikofil.rs: „У последњих неколико дана у српски медијски (и интернет простор) усељава се и једна сасвим нова реч - ковидиот. Ковидиот означава особу која не зна, не разуме, не увиђа или не жели да зна за опасност од вируса ковид 2019. Истовремено, незнање прати и одређено понашање, другачи(је од препорученог: ковидиот не поштује мере дистанцирања, изолације, карантина, те тиме угрожава и себе и друге.” „Реч је настала сливањем две речи: ковид (назив за болест коју изазива најновији мутирани вирус из породице коронавируса) и идиот”. Њихова су предвиђања и да ће ова новоскована реч постати интернационални неологизам, а томе у прилог иде чињеница да је „за врло кратко време, продрла у српски језик, али и у друге језике: засад је има у француском, немачком, италијанском, шпанском, турском, грчком, чешком...”.
} 


\subsubsection{4. Син т аг матски сп о је в и}

Бројни су и различити синтагматски спојеви ових двеју (корона и ковид) и неких других речи.

\subsubsection{1. Корона + именица:}

Џон Изнер је решио да поздрави „корона браћу”; у оквиру своје корона дипломатије; на међународном такмичењу „Корона иноващије”; Добили смо најбољу корона кореографију; Корона криза може да доведе до рата; Како паушалац подиже корона минималащ; КОРОНА ПОШАСТ У ПРЕМИЈЕР ЛИГИ; У српским хотелима осмишљен КОРОНА прибор; Дневни корона радар; обавезно именовање лица - корона редара од стране одређених; Корона прогнозе за регион Србију; ушле су у црну корона зону и то забрињава; Тим освојио своју другу „корона титулу”; Шта значи „соrona free” и сл.

Овде се могу сврстати и модели типа: После ковида, посткорона синдром; започео посткоронско доба итд.

Ретки су трочлани модели: „Корона вирус дипломатија неће променити пут Србије".

У Речнику појмова из периода епидемије ковида налазимо: корона време, корона журка, корона забава, корона закон, корона изазов, корона криза, корона лудило, корона мем, корона мере, корона обвезнице, корона парти, корона правила, корона профитер, корона режим и корона шопинг.

3.3.3.4.2. За сада се модел именица+корона није показао продуктивном: Усред ,кризе корона”.

\subsubsection{3. Ковид + именица:}

Дезинфекција у ковид амбуланти у Дуваништу; Језива исповест доктора из ковид болнице; да се плата не смањује због „ковид боловања”; Добио је један Ковид контејнер; Фабрици: Ковид криза је зближила Србију и ЕУ; Ево која су задужења ковид (COVID) менацера; Седморо пацијената примљено је на ковид одељења; припала је Ковид одељењу; бање излазе из ковид режима; ванредни ковид рок; Земун излази из ковид система; Када добијемо резултате ковид тестова итд.

У Речнику појмова из периода епидемије ковида налазе се само два примера овога типа: ковид амбуланта и ковид болница.

Јавиле су се и трочлане синтагме овога типа (ковид + придев + именицุа): ковид позитивних пацијената.

\subsubsection{4.Именица + ковид}

Пирот је добио контејнер Ковид; Обезбеђено је укупно 100 контејнера Ковид; Ускоро ће изаћи из статуса ковида (болница) итд.

И ово је обећавајуће фреквентан модел, те је појава нових очекивана.

О творбеној маштовитости сведочи пример ковид 81: Афера добила надмак „ковид 81" (према богатом 81-годишњем морнару, који је донео и проширио вирус на острво Брач у Хрватској). 
3.3.4.5. Н е к о в и д. Изгледа да је веома брзо настао антоним - нековид, тј. некада у писању и не-ковид. Овај лик се јавља у комбинацији са којом другом речју - у облику полусложенице или као синтагма:

функцију нековид болнище; Најважнији нековид догађај у Нишу; Било да је ковид или нековид пацијент; вратити болницу у „нековид-режсим" и сл.

За не-ковид болеснике предвиђено је...

\subsection{5. Глаголи и придеви}

За сада је у говору доста фреквентан глагол коронирати се и облици настали од њега (Хоћете да се искоронирате), а појава придева је у мојој грађи раритетна: Короносална идеја (наслов); преко короносалне идеје да распише (податак из листа Данас од 10. 6. 2020) ${ }^{15}$ и посткоронско доба.

У Речнику појмова из периода епидемије ковида помиње се више придева: ковидан, антикоронски, ковидпозитиван ${ }^{16}$, коронавирусни, коронзиван и коронски. У овом речнику је са префиксоидом пост- забележен придев посткоронски.

\section{4. Језичко-правописна решења}

Као што се могло видети у претходном делу, будући да су примери преношени у оригиналу, правописна (а и језичка) проблематика је различито решавана.

На cajтy https://bif.rs од 18. марта 2020. налазимо податке да је у почетку овај вирус називан Вухан вирусом, затим Вухан коронавирусом, да би потом постао кинески коронавирус. Такви детаљи утицали су да дође до недоумица у вези са називом и вируса и болести широм света. Тамо такође стоји да је 11. фебруара 2020. године на сајту Светске здравствене организације болест изазвана овим вирусом названа Covid- $19^{17}$. Тако се дошло до разлике у називу за вирус (корона) и болест коју тај вирус изазива (SARS-CoV-2, тј. ковид-19). На том сајту налази се и термин "virus odgovoran za Covid-19", као и “Covid-19 virus", што се претходноме противи, тј. уноси забуну у вези са називом болести и узрочника те болести.

Осврт на проблем писања ових ликова налазимо на сајту https:// jezikofil.rs (7. 2. 2020): „У домаћим медијима налазимо различита решења за писање овог новог смртоносног вируса, али док не добије званично име, ко-

\footnotetext{
${ }^{15}$ Аутор овог чланка је Надежда Миленовић, те је она вероватно и осмислила овај придев.

16 Занимљив је податак да је илустративни материјал у овоме Речнику имао или две лексеме - ковид позитиван или сложеницу ковид-позитиван.

17 Занимљиво је размишљање Г. Благус Бартоломец: „Слово с изговара се као к те би запис требало фонетизирати и писати ковид 19, односно ковиб 19 ако се у хрватскоме енглеска ријеч disease замијени ријечју болест."
} 
ристићемо и даље назив целе групе, који ћемо писати, као што и наши приручници предлажу - састављено. Наиме, постојећи приручници још увек не пишу о овом типу вируса, али се придржавају правила које се примењује и у научној терминологији, а то је да се спојено пишу називи групе вируса (нпр. рабдовируси, реовируси, ретровируси и сл.), а одвојено уколико се ради о вирусу болести коју он изазива (нпр. ХИВ вирус / вирус ХИВ-а, ебола вирус / вирус еболе, рубеола вирус / вирус рубеоле и сл.)."

На ову проблематику осврнули су се и неки домаћи писани и видео медији.

На сајту https://bif.rs/2020/03/ истиче се неслагање лингвиста у вези са овим - једни су присталице одвојеног писања са лексемом вирус у првом делу (вирус корона) позивајући се на то да су то атрибутивне синтагме, а други су мишљења да је потребно писати заједно (коронавирус), као што се пише рабровируси, ретровируси и сл.

Одбор за стандардизацију језика (31. октобра 2020. под насловом Пиcaње једног вируса) предлаже и образлаже да треба употребити двочлану синтагму вирус корона ${ }^{18}$, „У складу с начином писања у српском језику, најисправније је писати: вирус корона, дакле, тако што се реч вирус пише на првом месту. Наиме, ова конструкција у српском језику потпада под атрибутивне конструкције, а правило је да у свим таквим конструкцијама (синтагмама) шири појам долази испред ужег". ${ }^{19}$

За чланове Одбора није прихватљив ни економичнији термин корона: „У говорној пракси назив вируса означава се и без главног синтагматског дела (који се подразумева)"'20.

Истина, и они истичу: „Од лекарских стручњака сазнајемо да је назив вируса у форми coronavirus (у српском језику транслитерисан, пресликан као „коронавирус”) верификовао Међународни комитет за таксономију вируса. Позивајући се на ауторитет Међународног комитета за таксономију вируса, поједини стручњаци, али не само медицински, већ и неки лингвисти, сматрају да одлуке тога тела у погледу донетих терминолошких решења морају бити прихваћене свуда, па и у књижевном језику”, што чланови Од-

\footnotetext{
${ }^{18}$ Подаци о томе налазе се на http://www.ossj.rs.

${ }^{19}$ Рекло би се да се језички стручњаци помало љуте и тврде: „У пракси, међутим, то није тако, јер се, упркос поменутој препоруци Одбора, немали број новинара, али и државних званичника, оглушује о раније изнето мишљење Одбора (као стручног тела надлежног за питања језичке правилности и норме), употребљавајући варваризам „коронавирус” уместо нормативно исправне форме вирус корона".

${ }^{20}$ Они кажу: „Усталио се у језику назив корона - са нормативном препоруком вирус корона”, одакле испада да је тај термин „резервисан” за говорну праксу. Исто мисли и Г. Благус Бартоломец: „УЗ стандарднојезични назив коронавирус проширен је скраћени, колоквијални облик корона”. „Тај се назив не препоручује у службеној комуникацији” (Bartolomec 2011: $31)$.
} 
бора не прихватају ${ }^{21}$. Дакле, према мишљењу Одбора за стандардизацију српског језика правилно је вирус корона.

У вези са писањем ових лексема Иван Клајн (на сајту www.nin.co.rs) закључује: „Ни болести ни називи вируса и других микроорганизама код нас се не пишу великим словом."22

Чини се да је свака аргументована препорука оправдана, па се у том смислу чини оправданом тврдња Одбора за стандардизацију српског језика, али и оних који тако не мисле. Ставу одбора да је то полусложеница без спојног вокала може се одговорити да српски језик познаје и сложенице без спојног вокала ${ }^{23}$. У прилог овоме решењу иде и податак да је то (спојено) заправо име овог вируса (coronavirus).

\section{5. Уклопљеност у језички (падежни) систем}

Свака новопридошла реч настоји да се уклопи у језички систем у који улази и да се томе систему прилагоди. За лик корона уклапање у српски језички систем било је лако, будући да је то именица женског рода на $-a$, a такве су бројне и обичне. То потврђују примери:

Од короне је у Србији преминуло; Ми не знамо хоће ли бити короне на зиму; Уживати напољу у доба короне; итд.

Упркос корони, хиљаду мртвих мање;

\footnotetext{
${ }^{21}$ „Такво становиште није оправдано, јер стандардизација термина у конкретном случају није подразумевала сарадњу медицинских стручњака и лингивиста нормативиста.” „Наведени називи вируса припадају сложеницама страног (интернационалног) порекла које се могу писати спојено, као што су и термини: кардиохирургија, коронарографија, стафилодермија итд., будући да су, формално гледано, у сагласју са творбеном структуром српског језика управо због постојања интерфикса (спојног вокала) $o$, који је, уз вокал $e$, својствен свим словенским језицима, па и српском.” „У случају варваризма „коронавирус” јасно је да није у питању композит већ пресликавање (транслитерација) речи стране језичке структуре.”

22 У хрватском је, према писању Горанке Благус Бартоломец, правилно писање коронавирус као једне речи, а тако, по њој, треба писати и коронаболница, коронафобија, коронакриза и сл. Г. Б. Бартолец је мишљења да назив болести треба писати великим словима и бројем са цртицом, будући да је тако службено регистрован.

Словенци су такође разрешавали ову дилему („Kako pisati in sklanjati izraze „koronavirus” in bolezen „,covid-19” ali „koronavirusna bolezen 2019”) и закључили: „О koronavirusu lahko že v Slovarju novejšega besedja iz leta 2013 in drugi izdaji SSKJ (2014) preberemo, da gre za samostalnik moškega spola, ki označuje virus iz družine z latinskim imenom Coronaviridae. Kot vse podobne zložene besede ali zloženke (adenovirus, enterovirus, rotavirus, retrovirus) tudi koronavirus pišemo v slovenščini kot eno besedo, izgovarjamo pa ga z dvema naglasoma. (Izgovor z enim samim naglasom koronavírus ni upravičen.)" Подаци су преузети са сајта https:// svetovalnica.zrc-sazu.si преузето 16. 1.2021.

${ }^{23}$ У граматищи српског језика Ж. Станојчића и Љ. Поповића стоји: „Између основа речи које учествују у слагању може стајати и инфикс - спојни вокал (-о-, односно -е-) (Станојчић, Поповић 2011: 147).
} 
На захтев грађана тест на корону; Признао да је имао корону; ширила корону по Скопљу итд.

У Немачкој 168000 заражено короном, И 89 заражено короном итд.

У српски језички систем једноставно је било уклопити и сложеницу коронавирус као именицу мушког рода на сугласник:

Број новозаражених од коронавируса у паду; потврђено је присуство коронавируса; Током нове пандемије коронавируса итд.

Да је повезан са коронавирусом; у свету коронавирусом заражено 4 милиона итд.

И назив ковид лако се уклопио као именица мушког рода:

Од ковида је у Србији досад излечено; Улазак ковида у Институт; Смртност од ковида у Србији; спремни за последице ковида итд.

Моја прича са ковидом је гомила питања; Нулти пацијент са ковидом; Од броја и стања пацијената са ковидом, борбу са ковидом изгубило итд.

То се често дешавало и када је ова лексема ишла с бројем:

Нема оболелих од ковида 19; Сви руски рецепти против ковида 19; Није имао симптоме ковида 19; ширење ковида 19 итд.

Било је и примера када се избегавала деклинација тако што је у препозицији додата лексема која је деклинирана: Хоспитализован је због инфекичије Цовид-19.

Но комбинација је остајала и без покушаја да се реши проблем деклинације: Троје инфицираних људи из Цовид-19; Русија је на петом месту у свету по броју оболелих од Ковид-19.

Оно што је било лако уклопиво употребом једночлане лексичке јединице изгледа није било лако у случају синтагматског модела са лексемом корона (у првом или другом делу) - у том случају ово корона остајало је непроменљиво. То потврђује употреба у функцији свих падежа:

I. Број опорављених од корона вируса, током пандемије корона вируса; Оболело од корона вируса; Још новооболелих од корона вируса.

Број заражених корона вирусом; Не можете два пута бити заражени корона вирусом; у борби са корона вирусом итд.

Преглед гласина и лажних вести о корона вирусу, информације о корона вирусу.

II. Новооболелих од вируса корона; против вируса корона; Са последицама вируса корона; потпуног излечења од вируса корона итд.

Број заражених вирусом корона; Вирусом корона су се заразили скијаши; Од инфекције вирусом корона.

Када је реч о вирусу корона итд.

Овоме се придружила и употреба синтагме са лексемом ковид - она је ообично остајала индеклинабилна без обзира на њен положај:

Потврђено 67 нових случајева вируса ковид-19;

Почетак целе ситуације са вирусом COVID-19; 
На сајту https://covid19.rs стоји: O-covid-19-virusu, као један вид наслова.

Претходној тврдњи противречи пример: Ускоро ће изаћи из статуса ковида (болница), са променљивошћу оба дела.

У српскоме језику, колико је мени познато, није било осврта на ову проблематику. У пракси се употребљавају различити облици: ковид 19, ковид-19, Ковид-19, Ковид 19, COVID-19, COVID19, covid-19, Covid-19, али најфреквентнији су ковид-19 и ковид19, што указује на смер у коме ће употреба преовладавати.

\section{6. Закључна разматрања}

Термини у вези са новонасталим вирусом ушли су насилно у готово све језике света и у њима траже своје место. Тако је и у српском језику. Две су основне лексичке јединице - корона и ковид, иако је ова друга заправо настала од прве, а прва је са другачијим значењем већ постојала. Те две лексеме „основале” су бројну породицу и сваког дана је увећавају. Проширивање породице одвија се на начин који је уобичајен у српском језику граде се нове речи деривацијом, композицијом или се јављају синтагматски спојеви са овим речима (ковидаи, ковидиот, ковид-амбуланта, ковид болница). Број тих новостворених, поготово двочланих (и вишечланих) лексема сваког дана се увећава јер се изнова јавља потреба за новим комбинацијама.

Овај процес је сличан ономе који се одвија и у другом језицима. У вези са овим новонасталим речима и изразима јављају се најмање два спорна питања - творба (коронавирус, корона вирус или вирус корона) и правописно решење (ковид, Ковид, Covid или COVID).

Језички стручњаци се засад стидљиво оглашавају тим поводом. Једино је било коментара и предлога у вези са писањем назива за вирус и јавила су се два предлога - вирус корона и коронавирус. За овај први изјаснио се Одбор за стандардизацију српског језика. Међутим, како пракса показује, тешко је језик општења сатерати у окове правила - он усваја правила фреквентности употребе, а употреба се често поводи за страним моделом и преузима га у оригиналу у мери у којој је то могуће или се устаљује неки други лик. Тек ће време показати које решење ће бити прихваћено - оно које је по мишљењу лингвиста једино исправно или оно које то није, али је фреквентно и као такво се наметнуло већини (или свима). Сигурно је да ће у говору још дуго бити лутања од вириса корона преко корона вируса до коронавиру$c a\left(\right.$ само у писањ $\left.{ }^{24}\right)$.

У вези са писањем скраћенице ковид огласио се лингвиста И. Клајн подсећајући да се назив болести пише малим словом. Истина, има доста

\footnotetext{
${ }^{24}$ Оно што важи за словеначки језик - да ова реч има два акцента, мора важити и за српски.
} 
шаренила кад је у питању писање овог облика, али најфреквентнији су ковид-19 и ковид 19, одакле је очигледно да је чињеница о којој говори Клајн јасна (а ваљда и позната) већини, али о писању броја уз овај облик, вероватно ће још бити недоумица, па ће се паралелно писати са цртицом и без ње.

\section{Извори и литература}

I

Дневни лист Новости;

Дневни лист Данас;

Дневни лист Курир

Дневни лист Политика

http://covid19.rs Посећен 2. 2. 2021.

www.politika.rs Посећен 2. 2. 2021.

II

Станојчић, Поповић, 2011: Живојин Станојчић, Љубомир Поповић, Граматика српског језика, Београд: Завод за уџбенике.

PMC: Речник српскохрватског књижевног језика, књ. 1-3, Н. Сад - Загреб: Матица српска - Матица хрватска, 1967-1969, књ. 4-6, Нови Сад: Матица српска, 1971-1976.

РCJ 2011: Речник српског језика, Нови Сад: Матица српска.

III

Blagus Bartolec, 2020: Goranka Blagus Bartolec „Jezik u doba korone”, Hrvatski

jezik, vol. 7, br. 2, 2020, str. 30-32. https://hrcak.srce.hr Пос. 23.1. 2021.

http://www.isj.sanu.ac.rs Посећен 15. 2. 2021.

https://bif.rs'/2020/03 Посећен 20. 6. 2020.

https://jezikofil.rs Посећен 7. 6. 2020.

http://www.ossj.rs/odluke-i-saopstenja Посећен 20. 12. 2020.

http://www.nin.co.rs Посећен 23. 1. 2021.

https://svetovalnica.zrc-sazu.si Посећен 12. 2. 2021.

https://covid19.rs Посећен 2. 2. 2021.

http://jezik.hr/koronavirus. Посећен 3. 2. 2021. 
Иордана С. Маркович

\title{
ВХОД КОРОНЫ В СИСТЕМУ СЕРБСКОГО ЯЗЫКА
}

\begin{abstract}
Резюме
Беда, обрушившаяся на весь мир с конца 2019 года в виде появления и агрессивного распространения нового, доселе неизвестного вируса короны, должна была найти свое место в языковой системы. В этой статье на материале сербского языка показано, в какой степени увеличивается семейство слов в связи с вирусом и вызываемым им заболеванием, а также то, как эти лексемы формируются, пишутся и соответствуют в систему сербского языка, как и дороги которыми будет происходить дальнейшее расширение.
\end{abstract}

Ключевые слова: корона, ковид, лексема, синтагма, языковая система. 